\title{
Seasonal adaptations of green lacewings (Neuroptera: Chrysopidae)
}

\author{
MichEL CANARD
}

47 chemin Flou de Rious, F-31400 Toulouse, France; e-mail: michel.canard@wanadoo.fr

Key words. Chrysopidae, green lacewing, seasonal adaptation, diapause, voltinism, overwintering, cycle synchronization, wintering chambers

\begin{abstract}
Seasonal adaptations of green lacewings (Neuroptera: Chrysopidae) and their role in the control of aphid populations are discussed. The chrysopids of temperate zones face seasonal changes and must escape cyclic adversity. One way is via the number of broods per year. Most green lacewings are facultatively multivoltine, with the succession of generations most often regulated by photomediated diapause. Others are univoltine and some extend their life-cycle to two years in cold or dry environments. Synchronization is an important feature of seasonality, often starting in spring. In univoltine species, it is sometimes the result of subtle mechanisms, such as double contradictory signals (short plus long day lengths) for reactivation in spring, or a multi-receptivity of the preimaginal instars to photoperiod throughout a year, combined with photo-controlled and synchronized egg laying in late summer. Only one North American species is known to enter a surnumerary food-mediated diapause in summer. Every postembryonic instar may undergo diapause depending on the species. The timing and impact of the spring resumption in aphid consumption depends on their overwintering strategy.

As far is known, chrysopids are intolerant of freezing, but their supercooling points are low enough to enable them to endure hard frost. The numbers of overwintering specimens of green lacewings in the field depend on the structure of the assemblages in the previous growing season. Three examples are used to show that the overwintering populations are different in the different biotopes and dependent on the way the dominant species overwinter. Artificial chambers proposed for overwintering adults of common green lacewings afford them protection during diapause and enhance their predatory efficiency in spring.
\end{abstract}

\section{INTRODUCTION}

Organisms living at the higher latitudes are regularly confronted with seasonal changes in climate (cold/hot or dry/wet), which are more or less rigorously adverse and result in the evolution of strategies for escaping this cyclic adversity. In arthropods, diapause and/or migration may offer ways of doing this. As far is known, Chrysopidae only use diapause. True migration (sensu Kennedy, 1975) may occur, but only, as far is known, in Chrysoperla carnea (Stephens, 1836), the so-called "common green lacewing", which obligatorily flies down-wind on the first two nights after emergence, whatever the generation (Duelli, 2001).

\section{WHICH SPECIES OF GREEN LACEWING ARE INVOLVED?}

About 1200 species of Chrysopidae are described (Brooks \& Barnard, 1990). Most are inhabitants of the tropical and equatorial zones and display homodynamic development. They do not experience a seasonal alternation of favourable and adverse climatic and trophic conditions. This is the case for instance in the Afrotropical Mallada desjardinsi (Navás, 1911) (Brettell, 1979) and the Neotropical Chrysoperla externa (Hagen, 1861) (Macedo et al., 2003). In Ceraeochrysa cincta (Schneider, 1851), C. cubana (Hagen, 1861) and C. smithi (Navás, 1914), diapause was not observed even at $30^{\circ} \mathrm{N}$ in Florida and Texas, nor induced experimentally in the laboratory (López-Arroyo et al., 1999).

Green lacewings in the Holarctic Region show adaptations to the seasonal changes; diapause is not recorded for any lacewing in the southern hemisphere. The quite wellstudied Westpalaearctic Region harbours about 121 species of chrysopids (Aspöck et al., 2001), 67 of them occur in Europe; in the Nearctic Region, 82 species are recorded in North America, excluding Mexico (Penny et al., 1997, 2000). It is mainly by studying these species that we can understand the mechanisms by which they survive and efficiently colonize the available biotopes every year. Here their impact on the control of aphid outbreaks will be assessed rather than the physiological mechanisms by which this is achieved.

\section{VOLTINISM}

A commonly encountered method of adjusting annual cycle is the number of broods per year, i.e. univoltinism vs multivoltinism, which affects the impact these predators have on aphids. Responses are variable and not dependent only on the latitudinal occurrence of a species. For example, Ceraeochrysa placita (Banks, 1908), reported from Canada to Mexico, does not enter dormancy in order to survive winter in the southern part of its range; nevertheless, it is always univoltine (Tauber et al., 1998).

Other species have more varied patterns of voltinism, such as the stenotopic Chrysopa phyllochroma Wesmael, 1841 and Chrysopa dasyptera McLachlan, 1872, which are univoltine in Central Europe according to Zelený $(1965,1984)$; but Ch. phyllochroma may have two generations a year in western Europe (Trouvé et al., 2002) and $C h$. dasyptera has two generations a year in the Middle Volga Region in Russia $\left(52-54^{\circ} \mathrm{N}\right)$ (Kovrigina, 
1990). In the case of facultative uni/multivoltinism, some individuals of a species mostly only show a slight response depending on their place of origin, as in Chrysopa abbreviata Curtis, 1834, in Italy (Pantaleoni, 1982). Nevertheless, most green lacewings exhibit facultative multivoltine cycles with the number of broods per year a direct function of the climatic and trophic conditions.

Some species manifest a tendency to prolong and maintain diapause for more than one year and so have a twoyear cycle. This precaution against unfavourable environmental conditions is adopted in northern, cold countries, e.g. by Chrysopa dorsalis Burmeister, 1839, in Russia (Volkovich, 1998), and in xerothermic conditions, e.g. by the Iberian Chrysopa regalis Navás, 1915 (Canard, 1986a). This particular adaptation involves species diapausing as prepupa within a cocoon, since this is the only stage able to provide protection against dehydration and weight loss (Canard et al., 1996).

\section{CUES REGULATING VOLTINISM}

When "obligatory" (i.e. always manifested in natural conditions) univoltinism is a totally innate function, genetically mediated (Tauber \& Tauber, 1981; Tauber et al., 1986). On the other hand, as in most arthropods exhibiting facultative multivoltinism, photoperiod is the main factor regulating the cycle, more or less modulated by temperature and/or thermoperiod, as in Dichochrysa flavifrons (Brauer, 1850) (Principi et al., 1990), Chrysopa pallens (Rambur, 1838) (Orlova, 1998) and Dichochrysa prasina (Burmeister, 1839) (Volkovich, 1998) in northern Russia.

\section{ARE GREEN LACEWINGS FROST TOLERANT?}

Whether uni- or multivoltine, chrysopids in temperate climates experience low temperature in winter. There is little information on the ability of green lacewings to resist cold. The available data indicate a good hardiness to frost even if the green lacewings are unbiased frost intolerant.

Prepupae of Chrysopa perla (Linnaeus, 1758) on the sixth month of diapause are unable to survive 3 days at $-17^{\circ} \mathrm{C}$, but can survive $-6^{\circ} \mathrm{C}$ (Sagné \& Canard, 1984). Overwintering adults of the common green lacewings in North America survived well (97\%) 31 weeks at $5^{\circ} \mathrm{C}$ when in a diapause-inducing photoperiod (Tauber et al., 1993). This is better than expected, based on their thermal thresholds of development, which are estimated to be 11-12 or $8-9^{\circ} \mathrm{C}$ in Chrysopa perla originating from western Europe (Canard \& Principi, 1984) and Central Russia (Volkovich, 1998), respectively, and about $10^{\circ} \mathrm{C}$ in northeastern European strains of common green lacewings (Volkovich, 1998). The supercooling point (SCP) of common green lacewings is $-12.6^{\circ} \mathrm{C}$ in September, $-17.3^{\circ} \mathrm{C}$ in November and $-6.5^{\circ} \mathrm{C}$ in April in France (Vannier, 1986, 1987). The diapausing young larvae of Nineta pallida (Schneider, 1846) have a SCP of $-25^{\circ} \mathrm{C}$ in first instar ex-ovo and $-17.9^{\circ} \mathrm{C}$ during winter (Vannier \& Canard, 1989; Canard \& Vannier, 1992).
Little is known about the physiological mechanism of their cold hardiness, but cryoprotection in Neuropterida probably does not differ from that in other insects. In overwintering cocoons of Chrysopa walkeri McLachlan, 1893, carbohydrate analysis shows glycogen and trehalose as the major stored elements. The glycogen level was consistantly higher than that of trehalose, whilst polyol levels were low or undetectable (Sagné et al., 1986). Overwintering adults of Chrysoperla affinis (Stephens, 1836) [Chrysoperla kolthoffi (Navás, 1927)] showed a strong decrease in total lipid content at the beginning and at the end of winter reproductive diapause; the percentage of phospholipids increased significantly during postdiapause, while that of glycerids decreased, especially in females (Lemesle et al., 1998).

\section{WHICH INSTARS OVERWINTER?}

In all species of green lacewings there is one, sometimes two, developmental stages which are able to survive adverse winter conditions, namely frost and scarcity, if not total lack, of prey. In the family Chrysopidae, depending on the species, all stages except the embryo, can overwinter. Thirty nine of the 67 species in Europe and 17 North American species overwinter as a prepupa within a cocoon (Table 1).

\section{OVERWINTERING OF FIELD POPULATIONS IN DIFFERENT BIOTOPES}

Aphid control is often determined early in a growing season, because if the aphid fundatrices encounter an abundance of natural enemies when they colonize plants, the resulting colonies are less numerous and when established, less crowded. Early occurrence of predators is a key factor in efficient aphid management.

The time of resumption of predatory activity by green lacewings depends on their overwintering strategy, which determines their impact on aphid abundance (Fig. 1).

- If they overwinter as partly grown larvae as in Dichochrysa spp., they start feeding on prey immediately;

- if they overwinter as prepupae within a cocoon, the first contact between the predator and the prey is delayed until the adults emerge if they are predacious, as in Chrysopa spp.;

- if they overwinter as adults, the impact on prey is delayed until reproduction (ovogenesis, mating) + embryogenesis are complete, as in the common Chrysoperla spp.,

- or even much more longer, if they overwinter as a prepupa which gives rise to a parental spring generation of adults having palyno-glycophagous habits, as is the case in Nineta, Chrysotropia and Cunctochrysa spp.

The abundance and stages of green lacewings that resume predatory activity in spring in a biotope are a function of the structure of the chrysopid populations present the previous year. Three examples of chrysopid assemblages (Thierry et al., in press) that differ in the percentages of species that overwinter as larvae, prepupae and adults, which is relevant to their spring occurrence (Table 2). 
TABLE 1. Overwintering stages of some Holarctic chrysopids.

\begin{tabular}{|c|c|c|c|c|c|}
\hline Species & $\begin{array}{c}1 \text { st } \\
\text { instar }\end{array}$ & $\begin{array}{l}2 \mathrm{nd} / \\
3 \mathrm{rd}\end{array}$ & $\begin{array}{l}\text { Pre- } \\
\text { pupa }\end{array}$ & Pupa & Imago \\
\hline \multicolumn{6}{|l|}{ European: } \\
\hline Nothochrysa fulviceps & & & $*$ & & \\
\hline Nothochrysa capitata & & & * & & \\
\hline Hypochrysa elegans & & & & $*$ & \\
\hline Italochrysa italica & & $*$ & & & \\
\hline Nineta flava & & & $*$ & & \\
\hline Nineta vittata & & & * & & \\
\hline Nineta guadarramensis & & & $*$ & & \\
\hline Nineta pallida & * & & & & \\
\hline Chrysotropia ciliata & & & $*$ & & \\
\hline Chrysopa perla & & & $*$ & & \\
\hline Chrysopa walkeri & & & * & & \\
\hline Chrysopa dorsalis & & & $*$ & & \\
\hline Chrysopa regalis & & & $*$ & & \\
\hline Chrysopa hungarica & & & * & & \\
\hline Chrysopa abbreviata & & & $*$ & & \\
\hline Chrysopa formosa & & & $*$ & & \\
\hline Chrysopa phyllochroma & & & $*$ & & \\
\hline Chrysopa commata & & & $*$ & & \\
\hline Chrysopa viridana & & & $*$ & & \\
\hline Chrysopa nigricostata & & & $*$ & & \\
\hline Chrysopa pallens & & & $*$ & & \\
\hline Dichochrysa flavifrons & & $*$ & & & \\
\hline Dichochrysa picteti & & $*$ & & & \\
\hline Dichochrysa iberica & & $*$ & & & \\
\hline Dichochrysa prasina & & $*$ & & & \\
\hline Dichochrysa zelleri & & $*$ & & & \\
\hline Dichochrysa ventralis & & $*$ & & & \\
\hline Dichochrysa clathrata & & * & & & \\
\hline Peyerimhoffina gracilis & & & & & $*$ \\
\hline Chrysoperla carnea & & & & & $*$ \\
\hline Chrysoperla affinis & & & & & * \\
\hline Chrysoperla agilis & & & & & $*$ \\
\hline Chrysoperla lucasina & & & & & $*$ \\
\hline \multicolumn{6}{|l|}{ Chrysoperla } \\
\hline mediterranea & & & & & $*$ \\
\hline Chrysoperla mutata & & & & & $*$ \\
\hline Rexa lordina & & & $*$ & & \\
\hline \multicolumn{6}{|l|}{ Cunctochrysa } \\
\hline albolineata & & & $*$ & & \\
\hline Cunctochrysa baetica & & & $*$ & & \\
\hline \multicolumn{6}{|l|}{ North American: } \\
\hline Ceraeochrysa placita & & $*$ & & & \\
\hline Chrysopa nigricornis & & & * & & \\
\hline Chrysopa oculata & & & $*$ & & \\
\hline $\begin{array}{l}\text { Chrysopa } \\
\text { quadripunctata }\end{array}$ & & & * & & \\
\hline Chrysopa slossonae & & & $*$ & & \\
\hline Chrysopa timberlakei & & & $*$ & & \\
\hline Chrysoperla adamsi & & & & & $*$ \\
\hline Chrysoperla downesi & & & & & $*$ \\
\hline Chrysoperla johnsoni & & & & & $*$ \\
\hline Chrysoperla mohave & & & & & $*$ \\
\hline Chrysoperla plorabunda & & & & & $*$ \\
\hline Meleoma dolicharthra & & & * & & \\
\hline Meleoma emuncta & & & $*$ & & \\
\hline Meleoma hageni & & & * & & \\
\hline Meleoma kennethi & & & $*$ & & \\
\hline Meleoma schwarzi & & $* ?$ & & & \\
\hline Meleoma signoretti & & & $*$ & & \\
\hline Total & 1 & 10 & 31 & 1 & 12 \\
\hline$\%$ & & & 58 & & \\
\hline
\end{tabular}

The first biotope is typical of an agro-ecosystem influenced by the Atlantic. This study was carried out at Loos-en-Gohelle, in the southern French part of the Flanders Plain, Pas-de-Calais, France $\left(50^{\circ} 27^{\prime} \mathrm{N}, 02^{\circ} 47^{\prime} \mathrm{E}\right)$. It is an agricultural area with a long tradition of vegetable and fruit production. The fields are of commercial type, all managed using soft cultural techniques, either integrated or strictly organic farming methods. Several crops: strawberry, potato, witloof, tobacco and kidney-bean and adjacent uncultivated biotopes were sampled.

This agro-environment had the poorest biocenotic richness (Margalef's index) and low indices of both diversity (Shannon) and equitability (Hurlbert) (Table 2). The single dominant species, Chrysoperla affinis, made up more than $2 / 3$ of the overwintering (and spring?) population. In such conditions, a good survival of adults over winter is a key factor. The protection against unfavourable climatic factors, such as humidity and predatory spiders, can be improved (McEwen \& Sengonca, 2001). Adequate food for adults, before and after diapause, is necessary to initiate diapause satisfactorily and later stimulate reproductive activity (Alrouechdi, 1982). Whatever help is supplied to the overwintering population of chrysopids, it will only have a slow and late affect on spring aphid colonization.

The second biotope is a continental mountain, montane spruce acidophilous forest (Code Natura 2000: 94.10), subalpine picea zone (Code Natura 2000: 42.21). The site is located in the Transylvanian Alps, near Sinaia, about $110 \mathrm{~km}$ north-west of Bucharest and $60 \mathrm{~km}$ south of Brasov, Romania $\left(45^{\circ} 21^{\prime} \mathrm{N}, 25^{\circ} 33^{\prime} \mathrm{E}\right)$, at an altitude of $810 \mathrm{~m}$, near to two small brooks in the Prahova valley. The vegetation comprises an arboreal canopy of Fagus sylvatica and the conifers Picea excelsa, Abies alba and Pinus silvestris, associated with diversity of shrubs such as Alnus incana and an herbaceous ground cover typical of forest glades.

This spontaneous altitudinal forest has the highest biocenotic richness, but a moderate diversity (Table 2), due to the strong dominance of the facultatively bivoltine Cunctochrysa albolineata (Killington, 1935), which is palyno-glycophagous in the adult stage. Mortality of the diapausing prepupae in cocoons during winter is mainly due to predation by small rodents and shrews within the litter, entomopathogenic fungi and also possibly prolonged immersion (Sagné \& Canard, 1984) in poorly drained soils. The resumption of predation of aphids by chrysopids is expected to be late, but may be marked when most of the larvae of the dominant chrysopid species reach the third stage.

The third example is typical of thermo-Mediterranean biotope. It is a spontaneous pine forest (Code Natura 2000: 95.40), in the Aleppo pine sub-zone (Code Natura 2000: 42.84). It is situated at an altitude of about $100 \mathrm{~m}$, in southwestern France, near Fontcouverte, in the Corbières, Aude, France $\left(43^{\circ} 10^{\prime} \mathrm{N}, 02^{\circ} 35^{\prime} \mathrm{E}\right)$. The soil is calcareous, arid and stony. The arboreal vegetation comprises Pinus halepensis, Quercus ilex and Cupressus sempervirens, and the shrub layer is composed of Buxus 


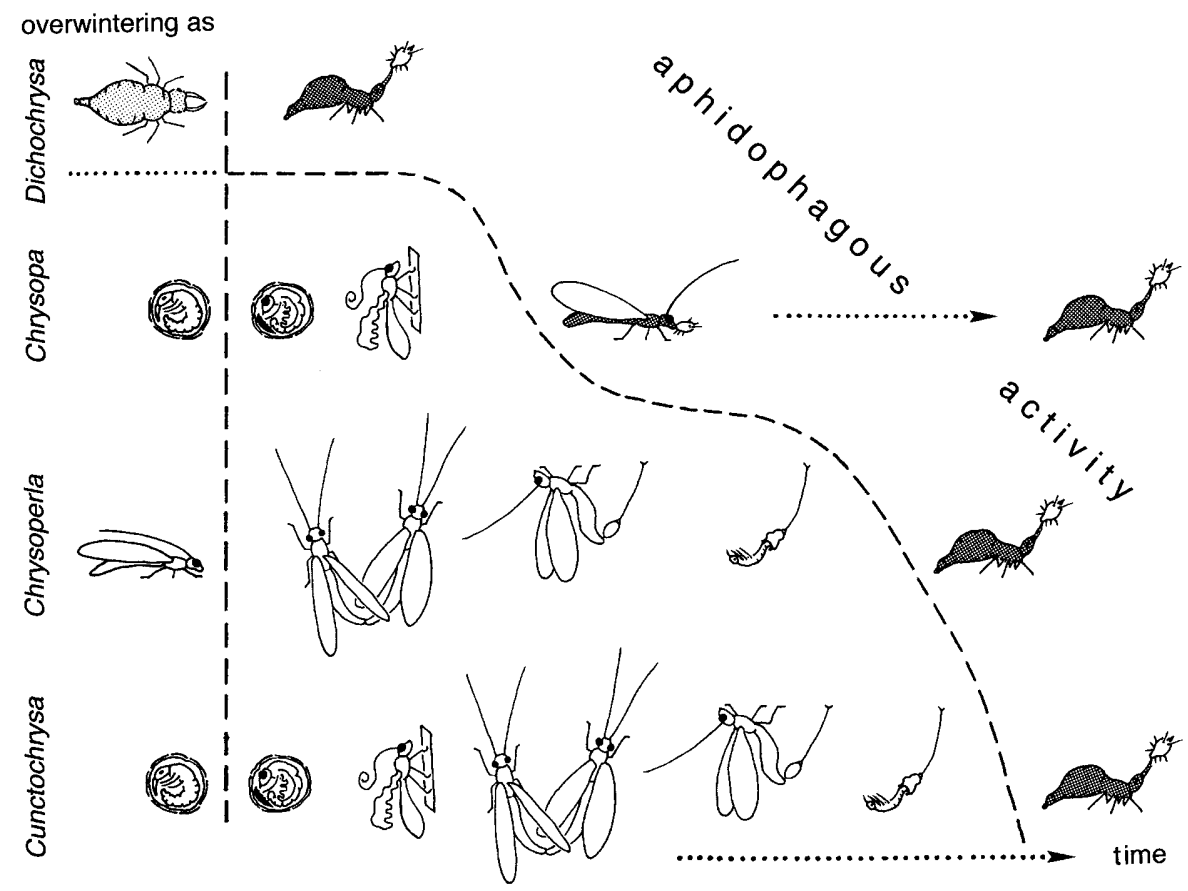

Fig. 1. Delay in the resumption of aphidophagous activity shown by green lacewings as a function of their overwintering strategy .

sempervirens, Quercus coccifera and Cistus spp. The herbaceous cover is irregular and essentially composed of the Mediterranean indicatory grass Brachypodium ramosum.

This arid and dry biotope is the most well-balanced of the three biotopes, and has a high richness, diversity and equitability (Table 2). Probably the most common instars overwintering are larvae. Mortality is due to generalist insectivores and a lack of suitable refuges. Their obligatory need to feed when the temperature reaches the thermal activity threshold means that starvation may also be a limiting factor. The pressure on live prey in such biotopes, experiencing mild winter temperatures, is semipermanent and so consistent control of aphids (or other prey) is expected.

\section{OVERWINTERING REFUGES}

Litle is known about actual overwintering sites of chrysopids. When larvae overwinter, they possibly do so on host plants, like the young naked larvae of Nineta pallida (Canard, 1985). But others, such as Dichochrysa spp., remain in low growing herbage or leaf litter (Bab- rikova, 1979) or under the bark of trees; they are often difficult to detect as they move little and are covered with debris.

The cocoons harbouring diapausing prepupae are thought to stay in the litter or remain hidden underground. In the laboratory, all the full-grown third instar larvae of Chrysopa perla crawl down into a small cavity in a dry and light substrate before weaving a cocoon; those that enter diapause hide themselves more than those that undergo on uninterrupted development (Canard \& Prudent, 1979). There is little information on the overwintering sites of other species, as cocoons are very rarely found in the field. Aggregations of cocoons of Chrysopa pallens are sometimes observed in the sawdust that accumulates from pruning branches of Robinia trees in urban areas.

Overwintering by adults is the most usual for the commonest green lacewings which many people think is the only way of overwintering in the Chrysopidae. Such a generalisation is possible because of the dominance of common green lacewings in agroecosystems and their dependance on man made structures (e.g. Gepp, 1967):

TABLE 2. Number of species and percentage of specimens of chrysopids overwintering in three typical biotopes. Percentages are those of the actual structure of relevant lacewing assemblages.

\begin{tabular}{|c|c|c|c|c|c|c|c|c|c|c|}
\hline \multirow{2}{*}{ zone and biotope } & \multirow{2}{*}{$\begin{array}{l}\text { number } \\
\text { of species }\end{array}$} & \multirow{2}{*}{$\begin{array}{l}\text { richness } \\
\text { index }\end{array}$} & \multicolumn{2}{|c|}{ diversity equitability } & \multicolumn{3}{|c|}{ No. species overwintering as } & \multicolumn{3}{|c|}{$\%$ specimens overwintering as } \\
\hline & & & index & index & larva & prepupa & imago & larva & prepupa & imago \\
\hline $\begin{array}{l}\text { atlantic: vegetable crops } \\
\text { dominant species }\end{array}$ & 5 & 0.92 & 0.8 & 0.4 & 1 & 3 & $\begin{array}{c}1 \\
\text { Ch. affinis }\end{array}$ & 1 & 28 & 71 \\
\hline $\begin{array}{l}\text { continental: montane forest } \\
\text { dominant species }\end{array}$ & 17 & 2.65 & 1.52 & 0.49 & 3 & $\begin{array}{c}12 \\
\text { C. albo- } \\
\text { lineata }\end{array}$ & 2 & 3 & 82 & 15 \\
\hline $\begin{array}{l}\text { mediterranean: spontaneous } \\
\text { dominant species }\end{array}$ & 13 & 1.94 & 1.95 & 0.74 & $\begin{array}{c}6 \\
\text { D. iberica }\end{array}$ & 5 & 2 & 55 & 5 & 40 \\
\hline
\end{tabular}


TABLE 3. Ground colour of the body of some Chrysoperla spp.

\begin{tabular}{|c|c|c|c|c|}
\hline Place & species & summer colour & & winter colour \\
\hline \multirow[t]{5}{*}{ Europe } & affinis & green & & brown \\
\hline & agilis & pale green & & mixed \\
\hline & carnea & pale green & & mixed \\
\hline & lucasina & & green & \\
\hline & mediterranea & & dark green & \\
\hline \multirow[t]{4}{*}{ North America } & adamsi & green & & mixed \\
\hline & downesi & & dark green & \\
\hline & mohave & vellow green & & vellow \\
\hline & plorabunda & green & & brown \\
\hline Middle East and North Africa & sillemi & pale green & & mixed \\
\hline
\end{tabular}

for a long time, the best and sole retreats were considered to be unheated parts of country houses, stables, barns and similar structures. Of course, other overwintering sites are available in the field, including rolled dead leaves, litter, underside of bark, abandonned wasp nests ... in all cases dry and dark places. After the sibling species of the carnea complex were recognized, it was demonstrated in central France that they each have a different and specific overwintering strategy (Thierry et al., 1994). Chrysoperla affinis is the only species found indoors in winter, but also in bushes at the end of spring. Chrysoperla lucasina (Lacroix, 1912) shelters in evergreen plants, such as ivy and cherry-laurel bushes, whilst Chrysoperla carnea sensu stricto is more thigmotactic and prefers dry rolled leaves that remain on trees or on the branches of understory bushes.

\section{IS IT POSSIBLE TO PROTECT OVERWINTERING ADULTS OF CHRYSOPERLA SPP.?}

We know both the sites used by overwintering adults and that the main cause of death is predators and diseases. This is why biocontrol programmes try to enhance survival. To the best of our knowledge, the Chinese were the first to provide artificial shelters for Chrysoperla nipponensis (Okamoto, 1914) (Wang et al., 1987). Later, successively Sengonca, McEwen (see review in McEwen \& Sengonca, 2001), Çaldumbide et al. (2002) and Thierry et al. (2002) provided more information on the Palaearctic common green lacewings and suggest ways of improving the overwintering chambers. These are only attractive to Chrysoperla affinis, the commonest species in the crops in temperate climates. Supplementary feeding before storage and after the temperature rise in spring is crucial for initiating diapause (Alrouechdi, 1982) and the resumption of reproductive activity.

\section{SEASONAL POLYPHENISM: CHANGE IN ADULT COLOUR}

Colour changes shown by overwintering adults of Chrysoperla spp. were for a long time considered to be obligatory, associated with diapause and subject to variation (see e.g. MacLeod, 1967; Tauber et al., 1970; Honěk, 1973). This now needs to be reappraised bearing in mind the diversity of species in this complex, as winter colour may be a means of recognizing sibling species (Table 3 ). The ground body colour of overwintering adults is a chromo-mimetic adaptation to particular overwintering sites (Duelli, 1992; Henry et al., 2001).

\section{YEARLY SYNCHRONIZATION}

For insects, synchronization of development with the seasons is important. Although the factors that inhibit development have been the object of many studies, the synchronization mechanisms are often neglected (Hodek, 2002) despite their being the main factor determining the successful termination of diapause.

\section{Multivoltine cycle}

The regulation of multivoltinism is relatively simple. The primary control is via photoperiod during development. Later, re-activation or deactivation of morphogenesis is regulated by (low) temperature as in several European Chrysopa spp. (Principi \& Castellari, 1970): thus, Ch. perla in which low temperature determines the timing of the annual cycle and the synchronization of the sympatric uni- and multivoltine strains (Gepp, 1975). However, the completion of diapause may sometimes be spontaneous, so that after a period of thermal quiescence, the resumption of development is initiated by temperature reaching the thermal threshold for activity, as in Chrysopa oculata Say, 1849, (Propp et al., 1969). In some cases, more subtle mechanisms may optimize the spring emergence. Thus, Dichochrysa picteti (McLachlan, 1880) overwinters as active third or younger instar larvae, depending on the date on which they hatch in autumn (Canard et al., 1992). The photoperiod induces a more or less intense slowing down of development: medium day lengths (early autumn) result in the longest diapause, short day lengths (late autumn) the shortest diapause. The marked variability in the different larval stages present in autumn is reduced or even disappears in spring (Canard, 2001).

\section{Univoltine cycle}

To be univoltine and synchronize one's life cycle is not easy to achieve. Adjusting univoltinism may be easy if dependent on a single climatic factor. The NorthAmerican Meleoma signoretti Fitch, 1856, as far is known, responds to a simple signal: the diapausing prepupa is re-activated only by long days (Tauber \& Tauber, 1975). But the annual cycle of other univoltine species may be synchronized by more complicated cues with possibly two consecutive periods of diapause development 
because the photoperiod response is not irreversibly lost by (a first) diapause completion in multireceptive insects (Hodek, 1999). The examples given below attest to such complexity.

At the end of preimaginal development, the strictly univoltine American Chrysoperla downesi (Smith, 1932) requires a sequence of short day lengths followed by a sequence of long day lengths to initiate ovarian maturation and so avert diapause. In the field, it overwinters as an adult until the natural photoperiod is long enough to re-activate reproduction (Tauber \& Tauber, 1976). The larvae of the European Peyerimhoffina gracilis (Schneider, 1851) are photo-insensitive unlike the pupae and the imagos. The same double exposure to short- followed by long day lengths is needed to stimulate reproductive activity. In the field, they enter and remain in diapause until spring (Grimal, 1988). Peyerimhoffina gracilis is commonly univoltine, however, early egg laying in spring could result in adults experiencing increasing day lengths and reproducing at the beginning of summer. Such an opportunistic bivoltinism, if possible, would be exceptional (Zelený, 1984 and in litt.)

The archaic nothochrysine Hypochrysa elegans (Burmeister, 1839) is univoltine in the field. In summer the prepupal instar within the cocoon is prolonged, which may be considered a short prepupal diapause. It then enters a second diapause as a pupa in the cocoon, which is terminated the next spring by yet unknown conditions (Grimal \& Canard, 1996).

The adults of Nineta flava (Scopoli, 1763) are present in the field from May to October (Plant, 1994) and so the species appears to be multivoltine, as suggested in the literature (Zelený, 1984). However, it is univoltine. The larvae do not exhibit a "quick-versus-delayed" response whatever the photoperiod they experience, but always diapause within the cocoon. The extended duration for adult emergence after overwintering depends on the photoperiod experienced by the larvae during their development: short day length induces an early spring appearance (and conversely). The long egg-laying period results from the occurrence of an imaginal reproductive diapause induced in some individuals by long (summer) days (Canard, 1986b).

The development of overwintering first-instar larvae of Nineta pallida is retarded by short days which act even at the beginning of embryogenesis (Canard, 1990). Later on, i.e. in spring, the rate of development of the second- and third-instar larvae is reduced in response to increase in day length (Canard, 1988). Thus slowed by natural photoperiod, the duration of preimaginal development lasts more than ten months, from September/October to June/July. The synchronization of egg-laying in autumn is possibly secured by an adult diapause mediated by long day lengths in summer.

\section{SUMMER DIAPAUSE}

In addition, a true summer diapause has only been demonstrated for one chrysopid species: the North American Chrysoperla mohave (Banks, 1938), a highly specialized desert-inhabiting species, which is surprisingly also predacious as an adult, unlike (? all) other Chrysoperla spp. In this green lacewing, as in most of the genus, diapause in the overwintering adults is induced by photoperiod. However, it also manifests a facultative reproductive diapause (aestivation), which is induced when starved under long day conditions, and terminated when prey become available (Tauber \& Tauber, 1973).

ACKNOWLEDGEMENTS. Deep-felt thanks are due to T. Volkovich (St. Petersburg, Russia) for pertinent comments on the manuscript and to both A. Whittington (Edinburgh, Scotland, UK) and an anonymous reviewer for improving and checking the English.

\section{REFERENCES}

Alrouechdi K. 1982: Bioécologie de Chrysoperla carnea (Stephens) (Neuroptera: Chrysopidae). Son Impact Entomophage en Vergers d'Oliviers. Ph.D. Université Paul-Sabatier, Toulouse, France, $227 \mathrm{pp}$.

Aspöck H., Hölzel H. \& Aspöck U. 2001: Kommentierter Katalog der Neuropterida (Insecta: Raphidioptera, Megaloptera, Neuroptera) der Westpaläarktis. Denisia 2: 612 pp.

BABRIKova T. 1979: Bioecological studies on the green deer (sic) fly (Chrysopa prasina Burmeister). Gradinarska Lozarska Nauka 16(4): 12-18 (in Bulgarian, English abstr.).

BRetTell J.H. 1979: Green lacewings (Neuroptera: Chrysopidae) of cotton fields in central Rhodesia. 1. Biology of Chrysopa boninensis Okamoto and toxicity of certain insecticides to the larva. Rhod. J. Agric. Res. 17: 141-150.

BRooks S.J. \& BARNARD P.C. 1990: The green lacewings of the world: a generic review (Neuroptera: Chrysopidae). Bull. Brit. Mus. Nat. Hist. (Entomol.) 59(2): 117-286.

Çaldumbide C., Faessel L., Travers M. \& Rat-Morris É. 2002: Utilisation des boîtes d'hivernage pour la survie hivernale de Chrysoperla kolthoffi (Navás) en Maine-et-Loire (49). Mise au point d'un élevage de Chrysoperla kolthoffi (Navás). In Deuxième Conférence Internationale sur les Moyens Alternatifs de Lutte contre les Organismes Nuisibles aux Végétaux. Lille, France. Imprimerie L'Artésienne, Liévin, France, p. 112 (abstract).

CANARD M. 1985: Caractéristiques bioécologiques de Nineta pallida (Schneider) (Neuroptera: Chrysopidae) dans les Pyrénées. Neuropt. Intern. 3: 175-185.

CANARD M. 1986a: Is the Iberian lacewing Chrysopa regalis a semivoltine species? Ecol. Entomol. 11: 27-30.

CANARD M. 1986b: A cautious strategy in the lacewing Nineta flava (Scopoli) (Neuroptera: Chrysopidae). In Gepp J. (ed.): Recent Research in Neuropterology. Proceedings of the Second International Symposium on Neuropterology. Hamburg, FRG, 1984. Thalerhof, Graz, Austria, pp. 145-150.

CANARD M. 1988: Seasonal change in photoperiodic response of the larvae of the lacewing Nineta pallida. Entomol. Exp. Appl. 47: 153-159.

CANARD M. 1990: Effect of photoperiod on the first-instar development in the lacewing Nineta pallida. Physiol. Entomol. 15: 137-140.

CANARD M. 2001: Long rather than short diapause-promoting photoperiods induce strong diapause in green lacewings (Neuroptera: Chrysopidae). Acta Soc. Zool. Bohem. 65: 163-168.

CANARd M. \& Principi M.M. 1984: Development of Chrysopidae. In Canard M., Séméria Y. \& New T.R. (eds): Biology of Chrysopidae. Series Entomologica 27. W. Junk, The Hague, pp. 57-75. 
CAnARd M. \& Prudent P. 1979: Étude au laboratoire du site de tissage du cocon par les larves de Chrysopa perla (L.) (Neuroptera: Chrysopidae). Entomol. Exp. Appl. 24: 11-21.

CAnard M. \& VANNIER G. 1992: Adaptations of preimaginal stages of Nineta pallida (Schneider) to frost and heat (Insecta: Neuroptera: Chrysopidae). In Canard M., Aspöck H. \& Mansell M.W. (eds): Current Research in Neuropterology. Proceedings of the Fourth International Symposium on Neuropterology. Bagnères-de-Luchon, France, 1991. Imprimerie Sacco, Toulouse, France, pp. 75-85.

Canard M., Grimal A. \& Hatté M. 1992: How does the green lacewing Mallada picteti (McLachlan) overwinter? (Insecta: Neuroptera: Chrysopidae). In Canard M., Aspöck H. \& Mansell M.W. (eds): Current Research in Neuropterology. Proceedings of the Fourth International Symposium on Neuropterology. Bagnères-de-Luchon, France, 1991. Imprimerie Sacco, Toulouse, France, pp. 87-93.

Canard M., Grimal A. \& Carvalho C.F. 1996: Weight changes during preimaginal development in green lacewings (Insecta: Neuroptera: Chrysopidae). In Canard M., Aspöck H. \& Mansell M.W. (eds): Pure and Applied Research in Neuropterology. Proceedings of the Fifth International Symposium on Neuropterology. Cairo, Egypt, 1994. Imprimerie Sacco, Toulouse, France, pp. 87-101.

Duelli P. 1992: Body coloration and colour change in green lacewings (Insecta: Neuroptera: Chrysopidae). In Canard M., Aspöck H. \& Mansell M.W. (eds): Current Research in Neuropterology. Proceedings of the Fourth International Symposium on Neuropterology. Bagnères-de-Luchon, France, 1991. Imprimerie Sacco, Toulouse, France, pp. 119-123.

Duelli P. 2001: Lacewings in field crops. In McEwen P.K., New T.R. \& Whittington A.E. (eds): Lacewings in the Crop Environment. Cambridge University Press, Cambridge, UK, pp. $158-171$.

GEPP J. 1967: Überwinterung von Chrysopa carnea Stephens (Planipennia: Chrysopidae). Entomol. Z. (Frankf. a. M.) 77: 113-114.

Gepp J. 1975: Die Generationenzahl von Chrysopa perla (Linnaeus) (Planipennia: Chrysopidae). NachrBl. Bayer. Entomol. 24: $60-63$.

Grimal A. 1988: Exigences photopériodiques du cycle de développement de la chrysope Tjederina gracilis. Entomol. Exp. Appl. 47: 189-194.

Grimal A. \& Canard M. 1996: Preliminary observations on the effect of photoperiod on the life cycle of the green lacewing Hypochrysa elegans (Burmeister) (Insecta: Neuroptera: Chrysopidae: Nothochrysinae). In Canard M., Aspöck H. \& Mansell M.W. (eds): Pure and Applied Research in Neuropterology. Proceedings of the Fifth International Symposium on Neuropterology. Cairo, Egypt, 1994. Imprimerie Sacco, Toulouse, France, pp. 119-127.

Henry C.S., Brooks S.J., Thierry D., Duelli P. \& Johnson J.B. 2001: The common green lacewing (Chrysoperla carnea sensu lato) and the sibling species problem. In McEwen P.K., New T.R. \& Whittington A.E. (eds): Lacewings in the Crop Environment. Cambridge University Press, Cambridge, UK, pp. $29-42$.

HoDeK I. 1999: Environmental regulation and some neglected aspects of insect diapause. Entomol. Sci. 2: 533-537.

HoDEK I. 2002: Controversial aspects of diapause development. Eur. J. Entomol. 99: 163-173.

HonĚK A. 1973: Relationship of colour changes and diapause in natural populations of Chrysopa carnea Stephens (Neuroptera: Chrysopidae). Acta Entomol. Bohemoslov. 70: 254-258.
KenNedy J.S. 1975: Insect dispersal. In Pimentel D. (ed.): Insects, Science and Society. Academic Press, New York, pp. 103-119.

Kovrigina A.M. 1990: Zone regularities of eco-faunistical distribution of lacewings in the Middle Volga Region. In Blagoveshchenskaya N.N. (ed.): Ecology of Insect and their Conservation. Ulyanovsk, Russia, pp. 57-61 (in Russian).

Lemesle A., Thierry D., Foussard F. \& Canard M. 1998: Preliminary study on lipids in Chrysoperla kolthoffi (Navás) during diapause (Neuroptera: Chrysopidae). Acta Zool. Fenn. 209: 141-144.

López-Arroyo J.I., Tauber C.A. \& Tauber M.J. 1999: Comparative life histories of the predators Ceraeochrysa cincta, C. cubana and C. smithi (Neuroptera: Chrysopidae) Ann. Entomol. Soc. Am. 92: 208-216.

Macedo L.P.M., Souza B., Carvalho C.F. \& Ecole C.C. 2003: Influencia do photoperiodo no desenvolvimento e na reproducão de Chrysoperla externa (Hagen) (Neuroptera: Chrysopidae). Neotrop. Entomol. 32: 91-96.

MacLEOD E.G. 1967: Experimental induction and elimination of diapause and autumnal coloration in Chrysopa carnea (Neuroptera). J. Insect Physiol. 13: 1343-1349.

McEwen P.K \& SEngonca Ç. 2001: Artificial overwintering chambers for Chrysoperla carnea and their application in pest control. In McEwen P.K., New T.R. \& Whittington A.E. (eds): Lacewings in the Crop Environment. Cambridge University Press, Cambridge, UK, pp. 487-491.

OrLOVA N.A. 1998: Effects of photoperiod and temperature in Chrysopa pallens (Rambur) (Neuroptera: Chrysopidae). Acta Zool. Fenn. 209: 195-202.

Pantaleoni R.A. 1982: Neuroptera Planipennia del comprensorio della Valli de Commacchio: indagine ecologica. Bol. Ist. Entomol. Univ. Bologna 37: 1-73.

Penny N.D., Adams P.A. \& Stange L.A. 1997: Species catalog of the Neuroptera, Megaloptera, and Raphidioptera of America, north of Mexico. Proc. Calif. Acad. Sci. 50(3): 39-114.

Penny N.D., Tauber C.A. \& DE León T. 2000: A new species of Chrysopa from Western North America with a key to North American species (Neuroptera: Chrysopidae). Ann. Entomol. Soc. Am. 93: 776-784.

Plant C.W. 1994: Provisional Atlas of the Lacewings and Allied Insects (Neuroptera, Megaloptera, Raphidioptera and Mecoptera) of Britain and Ireland. Biological Records Centre, Huntingdon, UK, 203 pp.

Principi M.M. \& CASTellari P.L. 1970: Ibernamento e diapausa in alcune specie di crisopidi (Insecta: Neuroptera) viventi in Italia. Atti Acad. Sci. Ist. Bologna Rend. (Ser. 12) 7: 75-83.

Principi M.M., Memmi M. \& Sgobba D. 1990: Influenza della temperatura sulla diapausa larvale di Mallada flavifrons (Brauer) (Neuroptera: Chrysopidae). Bol. Ist. Entomol. Guido Grandi Univ. Bologna 47: 37-55.

Propp G.D., Tauber M.J. \& Tauber C.A. 1969: Diapause in the neuropteran Chrysopa oculata. J. Insect Physiol. 15: $1749-1757$.

SAGNÉ J.-C. \& CANARD M. 1984: Les limites de la résistance au froid et à l'immersion des prénymphes en diapause de Chrysopa perla (L.) (Neuroptera: Chrysopidae). Neuropt. Intern. 3: 73-78.

Sagné J.-C., Moreau R., Canard M. \& Bitsch J. 1986: Glucidic variations in the lacewing Chrysopa walkeri during the prepupal diapause. Entomol. Exp. Appl. 41: 101-103.

TAUber C.A. \& TAUBer M.J. 1981: Insect seasonal cycles: genetics and evolution. Annu. Rev. Evol. System. 12: 281-308.

Tauber C.A., de León T., López-Arroyo J.I. \& Tauber M.J. 1998: Ceraeochrysa placita (Neuroptera: Chrysopidae): 
generic characteristics of larvae, larval descriptions, and life cycle. Ann. Entomol. Soc. Am. 91: 608-618.

TAuber M.J. \& TAuber C.A. 1973: Nutritional and photoperiodic control of the seasonal reproductive cycle in Chrysopa mohave (Neuroptera). J. Insect Physiol. 19: 729-736.

TAuber M.J. \& TAuber C.A. 1975: Natural daylengths regulate insect seasonality by two mechanisms. Nature 258: 711-712.

TAuber M.J. \& TAuber C.A. 1976: Developmental requirements of the univoltine species Chrysopa downesi: photoperiodic stimuli and sensitive stages. J. Insect Physiol. 22: 331-335.

Tauber M.J., Tauber C.A. \& Denys C.J. 1970: Adult diapause in Chrysopa carnea: photoperiodic control of duration and colour. J. Insect Physiol. 16: 949-955.

Tauber M.J., Tauber C.A. \& Masaki S. 1986: Seasonal Adaptations of Insects. Oxford University Press, New York, USA, $411 \mathrm{pp}$.

Tauber M.J., Tauber C.A. \& Gardescu S. 1993: Prolonged storage of Chrysoperla carnea (Neuroptera: Chrysopidae). Envir. Entomol. 22: 843-848.

Thierry D., Cloupeau R. \& JARry M. 1994: Variations in the overwintering ecophysiological traits in the common green lacewing West-Palaearctic complex (Neuroptera: Chrysopidae). Acta Oecol. 15: 593-606.

Thierry D., Rat-Morris É. \& Çaldumbide C. 2002: Selective attractivity of artificial overwintering chambers for the common green lacewing species of the Chrysoperla carnea (Stephens) complex in Western Europe (Neuroptera: Chrysopidae). Acta Zool. Acad. Sci. Hung. (Suppl. 2) 48: 351-357.

Thierry D., Deutsch B., Paulian M., Villenave J. \& Canard M.: Quantifying biodiversity in ecosystems by green lacewing assemblages. A method of assessment and typifying ecological landscapes. Agron. Sustain. Devel. (in press).
Trouvé C., Thierry D. \& Canard M. 2002: Preliminary survey of the lacewings (Neuroptera: Chrysopidae, Hemerobiidae) in agroecosystems in northern France, with phenological notes. Acta Zool. Acad. Sci. Hung. (Suppl. 2) 48: 359-369.

VANNIER G. 1986: Accroissement de la capacité de surfusion chez les adultes de Chrysoperla carnea (Insectes: Névroptères) entrant en diapause hivernale. Neuropt. Intern. 4: 71-82.

VANNIER G. 1987: Diminution de la capacité de surfusion chez les adultes de Chrysoperla carnea (Insectes: Névroptères) au cours de la diapause hivernale. Neuropt. Intern. 4: 211-219.

VANNIER G. \& CANARD M. 1989: Cold hardiness and heat tolerance in the early larval instar of Nineta pallida (Schneider) (Neuroptera: Chrysopidae) Neuropt. Intern. 5: 231-238.

VolKovich T.A. 1998: Environmental control of seasonal cycles in green lacewings (Neuroptera: Chrysopidae) from the forest-steppe zone of Russia. Acta Zool. Fenn. 209: 263-275.

WANG R., Zhou W.R. \& QIU S.B. 1987: [Augmentation of Chrysoperla sinica: storing overwintering adults for early spring release.] Chin. J. Biol. Contr. 3(2): 55-60 (in Chinese, English abstr.), abstract in Rev. Appl. Entomol. 76: 7526.

ZeLENÝ J. 1965: Lace-wings (Neuroptera) in cultural steppe and the population dynamics in the species Chrysopa carnea Stephens and Chrysopa phyllochroma Wesmael. Acta Entomol. Bohemoslov. 62: 177-194.

ZelenÝ J. 1984: Chrysopid occurrence in West Palaearctic temperate forests and derived biotopes. In Canard M., Séméria Y. \& New T.R. (eds): Biology of Chrysopidae. Dr W. Junk Publishers, The Hague, The Netherlands, Series Entomologica 27: $152-160$.

Received September 9, 2004; revised and accepted February 22, 2005 